\title{
Kesan Kandungan Fosfat Berbeza terhadap Pembentukan Morfologi Permukaan, Penghabluran, Fasa, Ikatan Kimia dan Kekuatan Mampatan Bio-kaca Sol-Gel Tersinter
}

(Effect of Different Phosphate Content towards the Surface Morphology Formation, Chemical Bond, Crystallization, Phase and Compressive Strength of Sintered Sol-Gel Bio-glass)

\author{
SYED NuZUl FADZli SYEd AdAM*, RoslindA SHAMSUdin, FiRUZ ZAINUdDIN \& MOHD REUSMAAZRAN YUSOF
}

ABSTRAK

Kajian ini bertujuan untuk mengkaji kesan kandungan fosfat berbeza ( $X=10,15$ dan 20\% mol) terhadap pembentukan morfologi permukaan, ikatan kimia, penghabluran, fasa dan kekuatan mampatan kaca sol-gel tersinter. Serbuk kaca gel dengan komposisi $50 \mathrm{SiO}_{2} .(50-\mathrm{X}) \cdot \mathrm{CaO} \cdot \mathrm{XP}_{2} \mathrm{O}_{5}$ (dalam peratusan mol) disediakan melalui kaedah sol-gel, dimampat membentuk pelet dan disinter pada suhu $1200^{\circ} \mathrm{C}$ selama 3 jam. Didapati bahawa dengan peningkatan kandungan fosfat, mikrostruktur kaca tersinter yang lebih padat terhasil disebabkan peningkatan pemadatan jasad, pengurangan keliangan ketara dan pembentukan butiran dan sempadan butiran berhablur yang lebih besar. Peningkatan sebanyak $20 \%$ mol kandungan fosfat meningkatkan vitrifikasi (fasa kekaca) pada permukaan kaca tersinter yang mana meningkatkan pemadatan jasad kepada $83.56 \%$, kekuatan mampatan pada 113 MPa dan penurunan peratusan penghabluran pada sekitar 66\%. Analisis EDS menunjukkan peningkatan kandungan fosfat menyebabkan peningkatan unsur Si-O pada fasa amorfus dan unsur P-O pada fasa berhablur. Analisis FTIR menunjukkan berlaku pemisahan fasa kaya fosfat dan fasa kaya silikat dan pada masa sama meningkatkan rangkaian tetrahedra silikat ( $\mathrm{Si}-\mathrm{O}$-Si) dan fosfat ( $P$-O-P) kaca tersinter. Peningkatan kandungan fosfat meningkatkan kumpulan berfungsi berkaitan fosfat hablur dan mengurangkan kumpulan berfungsi berkaitan silikat hablur. Ini menyebabkan peningkatan pembentukan fasa silikokarnotit, $\mathrm{Ca}_{5}\left(\mathrm{PO}_{4}\right)_{2}\left(\mathrm{SiO}_{4}\right)$ dalam matriks kaca tersinter dengan peningkatan kandungan fosfat yang ditunjukkan melalui analisis XRD.

Kata kunci: Bio-kaca; fosfat; kaca tersinter; kekuatan mampatan; sol-gel

\section{ABSTRACT}

This research aimed to study the effect of different phosphate content (X=10, 15 and 20 mol \%) towards the surface morphology formation, chemical bond, crystallization, phase and compressive strength of sintered sol-gel glass. Gel glass powder with composition of $50 \mathrm{SiO}_{2} .(50-\mathrm{X}) \mathrm{CaO} \cdot \mathrm{XP}_{2} \mathrm{O}_{5}$ (in mol percent) was prepared via sol-gel method, compress into pellets and sintered at $1200^{\circ} \mathrm{C}$ for $3 \mathrm{~h}$. It was found that, as phosphate content increased, denser microstructure of sintered glass was achieved due to enhanced body densification, less apparent porosities and formation of larger crystal grain and boundaries. Increased in $20 \%$ mol of phosphate content increased vitrification (glassy phase) on the sintered glass surface in which increased densifications to $83.56 \%$, compressive strength at $113 \mathrm{MPa}$ and reduced crystallinity percent at around 66\%. EDS analysis showed, as phosphate content increased, Si-O elements at amorphous phase and $P$-O elements at crytallized phase were also increased. FTIR analysis showed that, a separation of phosphate rich phase and silicate rich phase is occured and at the same time increased the silicate ( $\mathrm{Si}-\mathrm{O}$-Si) and phosphate $(\mathrm{P}-\mathrm{O}-\mathrm{P})$ tetrahedral network of the sintered glass. Increased in phosphate content also increased the functional groups related with phosphate crystal and reduces the functional groups related to silicate crystal. This caused increased of silicocarnotite, $\mathrm{Ca}_{5}\left(\mathrm{PO}_{4}\right)_{2}$ $\left(\mathrm{SiO}_{4}\right)$ phase formation in the sintered glass matrice as phosphate content increased as showed by XRD analysis.

Keywords: Bio-glass; compressive strength; phosphate; sintered glass; sol-gel

\section{PENGENALAN}

Kebolehupayaan serbuk kaca bioaktif (bio-kaca) yang boleh disinter merupakan faktor yang sangat penting dalam membangunkan teknologi penghasilan bahan implan yakni daripada perancah berkeliangan tinggi kepada bahan salutan bioaktif. Walau bagaimanapun, bahan kaca bioaktif ini mempunyai sifat mekanikal yang tidak bersesuaian dengan tulang hidup yang bersifat rapuh dan tidak mempunyai kekuatan mekanikal yang mencukupi menyebabkan bahan ini tidak sesuai digunakan terutamanya di bawah bebanan tinggi (Ma et al. 2010). Disebabkan itu, kajian yang dijalankan sebelum ini terhadap bahan kaca bioaktif dilihat terhad pada bentuk serbuk termasuklah yang bersaiz nano (Oliveira et al. 2013). Walau bagaimanapun, beberapa ciri dan sifat penting yang dimiliki oleh bahan kaca bioaktif ini menyebabkan bahan ini amat diperlukan dalam aplikasi 
yang lebih meluas termasuklah pada galas bebanan tinggi. Satu kaedah mudah dan ringkas yang boleh digunakan untuk meningkatkan kekuatan mekanikal kaca bioaktif adalah menerusi kaedah rawatan haba atau sinteran. Secara amnya, sinteran meningkatkan ketumpatan, darjah penghabluran dan mengurangkan keliangan kaca serta membentuk bahan seramik kaca yang mampu meningkatkan sifat mekanikalnya. Oleh itu, adalah tidak mustahil untuk menghasilkan bahan seramik kaca bioaktif dengan sifat mekanikal yang lebih hampir dengan tulang semula jadi. Walau bagaimanapun, penghabluran yang terhasil mengurangkan sifat kebioaktifan kaca (Peitl et al. 2001). Namun, penghabluran komposisi tertentu kaca yang disinter pada suhu tinggi didapati masih mampu mengekalkan sifat kebioaktifan in vitro yang baik serta sifat mekanikal yang dipertingkatkan (Peitl et al. 2012; Yang et al.2012). Maka, proses sinteran terkawal pada suhu yang optimum terhadap komposisi tertentu kaca mampu menghasilkan bahan seramik kaca bioaktif dengan kekuatan mekanikal yang mencukupi bagi tujuan bioperubatan yang spesifik. Tujuan kajian ini adalah untuk meningkatkan kekuatan mekanikal (kekuatan mampatan) bagi bahan kaca sol-gel melalui kaedah sinteran dan peningkatan komposisi fosfat untuk digunakan sebagai bahan implan tulang kortikal semula jadi. Tulang kortikal merupakan tulang berstruktur padat semula jadi yang terdapat dalam sistem rangka manusia dan mampu menampung galas bebanan tinggi. Sebagai rujukan, kekuatan mampatan bagi tulang kortikal manusia berada dalam julat antara 90 ke $230 \mathrm{MPa}$ manakala bagi tulang berongga pula berada dalam julat antara 2 ke $45 \mathrm{MPa}$ (Hannink \& Arts 2011). Maka, kajian ini meletakkan sasaran peningkatan kekuatan mampatan bahan kaca sol-gel tersinter untuk mencapai julat kekuatan bagi tulang kortikal semula jadi.

Kebanyakan kajian sebelum ini menjurus kepada bahan kaca bioaktif yang dihasilkan daripada kaedah peleburan konvensional dan melibatkan suhu dalam julat $1300-1500^{\circ} \mathrm{C}$ bagi meleburkan campuran serbuk bahan mentah (Arcos \& Vallet-Regi, 2010; Brovarone et al. 2008; Lin et al. 2012; Lombardi et al. 2013). Kandungan fosfat $\left(\mathrm{P}_{2} \mathrm{O}_{5}\right)$ dalam komposisi kaca berperanan sebagai pembentuk rangkaian kaca bersama dengan komponen utama silikat (Rahaman et al. 2011). Kajian mendapati bahawa, peningkatan kandungan fosfat sehingga $10 \%$ berat akan menyebabkan kaca kehilangan sifat kebioaktifan disebabkan peningkatan dalam kestabilan kimia kaca dan peningkatan nilai $\mathrm{pH}$ yang tinggi dalam larutan (Bizari et al. 2013; Ravarian et al. 2011). Disebabkan itu, kajian terhadap bahan kaca bioaktif yang diperoleh secara konvensional kebanyakannya menetapkan kandungan fosfat yang kurang daripada $8 \%$ bt. (Esfehani et al. 2013; Lin et al. 2012).

Kaedah kimia sol-gel dalam penyediaan bahan kaca bioaktif mula mendapat perhatian disebabkan luas permukaan dan darjah ketulenan bahan yang tinggi dihasilkan serta suhu pemprosesan yang jauh lebih rendah berbanding kaedah peleburan (Jones 2013). Bahan kaca sol-gel mempunyai julat komposisi bersifat bioaktif yang lebih luas dan kandungan silika yang tinggi sehingga 90\% mol dapat dihasilkan berbanding kaedah peleburan (Adams et al. 2013). Terdapat beberapa kajian terdahulu telah dijalankan mengenai kesan kandungan fosfat berbeza, namun perbincangan yang dibuat tidak mengaitkan kesan komposisi fosfat terhadap pembentukan morfologi permukaan, penghabluran dan kekuatan mampatan maksimum kaca sol-gel tersinter (Esfehani et al. 2013; Lin et al. 2012; Salinas et al. 2002). Tambahan lagi, peranan komponen fosfat dalam komposisi kaca adalah agak kompleks dan sehingga kini masih belum difahami sepenuhnya. Maka, objektif kajian ini adalah untuk mengkaji kesan kandungan fosfat berbeza $(10,15$ dan $20 \%$ mol) terhadap pembentukan morfologi permukaan, ikatan kimia, penghabluran, fasa dan kekuatan mampatan maksimum kaca perolehan sol-gel yang disinter pada suhu $1200^{\circ} \mathrm{C}$.

\section{BAHAN DAN KAEDAH}

Bahan kaca dengan kandungan fosfat berbeza iaitu 10, 15, dan $20 \%$ mol disediakan melalui kaedah sol-gel dengan menggunakan asid nitrik sebagai pemangkin. Bahan kimia pemula, ketulenan dan pengeluar yang digunakan dalam penyediaan kaca sol-gel ini ditunjukkan pada Jadual 1 . Asid nitrik sebanyak $1 \mathrm{~mL}$ dilarutkan ke dalam $40 \mathrm{~mL}$ air ternyahion sebagai medium hidrolisis. Bahan pemula kaca ditambah ke dalam larutan akues asid mengikut turutan seperti berikut iaitu $10 \mathrm{~mL}$ tetraethyl orthosilicate (TEOS) $\mathrm{Si}\left(\mathrm{OC}_{2} \mathrm{H}_{5}\right)_{4},(2,3$ dan $4 \mathrm{~mL}$ triethyl fosfat (TEP), $\mathrm{OP}\left(\mathrm{OC}_{2} \mathrm{H}_{5}\right)_{4}$ dan 8.0 gram kalsium nitrat tetrahidrat, $\mathrm{Ca}\left(\mathrm{NO}_{3}\right)_{2} 4 \mathrm{H}_{2} \mathrm{O}$ sementara proses pengadukan dijalankan secara berterusan. Setiap satu bahan pemula dikacau sekurang-kurangnya setengah jam bagi memastikan tindak balas kimia yang lengkap berlaku. Larutan tersebut diaduk lagi selama 40 min dengan menggunakan pengacau magnet untuk mendapatkan campuran yang homogen. Selepas proses pencampuran selesai, sol dimasukkan ke dalam bekas acuan plastik bagi tujuan pengejelan. Pembentukan gel dapat diperhatikan selepas sol dibiarkan selama 48 jam pada suhu persekitaran. Gel kemudiannya dipanaskan pada suhu $120^{\circ} \mathrm{C}$ selama 48 jam bagi tujuan pengeringan seterusnya pada suhu $600^{\circ} \mathrm{C}$ selama 3 jam bagi tujuan penstabilan.

Gel kemudiannya dikisar dengan menggunakan akik dan lesung untuk mendapatkan serbuk halus. Sebanyak 4.0 gm serbuk yang diperoleh ditekan dan dimampatkan melalui kaedah penekanan serbuk menggunakan tekanan $240 \mathrm{MPa}$ dengan saiz diameter acuan $12 \mathrm{~mm}$. Pelet kaca disinter pada suhu $1200^{\circ} \mathrm{C}$ selama 3 jam dengan kenaikan suhu $5^{\circ} \mathrm{C}$ seminit di dalam relau elektrik. Peratusan keliangan ketara dan pemadatan pelet kaca tersinter ditentukan melalui kaedah Archimedes. Morfologi dan komposisi unsur permukaan dianalisis menggunakan mikroskop imbasan elektron-pancaran medan (FE-SEM) dan spektroskopi penyerakan tenaga (EDS). Kumpulan berfungsi ditentukan melalui kaedah inframerah (FTIR). 
JADUAL 1. Senarai bahan kimia (reagen) utama yang digunakan dalam proses sol-gel

\begin{tabular}{clccc}
\hline No & \multicolumn{1}{c}{ Reagen } & Komposisi kimia & Ketulenan $(\%)$ & Pengeluar \\
\hline 1 & Tetraetil ortosilikat (TEOS) & $\mathrm{Si}\left(\mathrm{OC}_{2} \mathrm{H}_{5}\right)_{4}$ & $99.0 \%$ & Merck \\
2 & Kalsium nitrat tetrahidrat & $\mathrm{Ca}\left(\mathrm{NO}_{3}\right)_{2} \cdot 4 \mathrm{H}_{2} \mathrm{O}$ & $99.0-102.0 \%$ & Merck \\
3 & Trietil fosfat (TEP) & $\mathrm{OP}\left(\mathrm{OC}_{2} \mathrm{H}_{5}\right)_{4}$ & $99.0 \%$ & Merck \\
4 & Asid nitrik & $\mathrm{HNO}_{3}$ & Kepekatan $(70 \%)$ & Sigma Aldrich \\
5 & Air ternyahion & $\mathrm{H}_{2} \mathrm{O}$ & - & - \\
\hline
\end{tabular}

Penentuan fasa dan peratusan penghabluran dijalankan melalui penyerakan sinar-X (XRD). Peratusan kehabluran ditentukan dengan mengira peratusan amorfus seperti ditunjukkan pada persamaan 1.0 dan 2.0. Kawasan sejagat dan kawasan larasan ditentukan daripada diffraktogram XRD berdasarkan prosedur analisis peratusan kehabluran menggunakan perisian EVA (Bruker).

$$
\% \text { Amorfus }=\frac{\text { Kawasan sejagat-kawasan larasan }}{\text { Kawasan sejagat }} \times 100
$$

$\%$ Kehabluran $=100-\%$ Amorfus

Manakala kekuatan mampatan maksimum pelet kaca tersinter diuji menggunakan mesin pengujian universal (UTM). Setiap sampel kaca tersinter dengan kandungan fosfat berbeza dilabelkan sebagai SiCa4P (10\% mol fosfat), SiCa4P3 (15\% mol fosfat) dan SiCa4P4 (20\% mol fosfat).

\section{KEPUTUSAN DAN PERBINCANGAN}

\section{SIFAT FIZIKAL DAN MORFOLOGI PERMUKAAN}

Jadual 2 menunjukkan nilai yang diperoleh bagi ketumpatan pukal, keliangan ketara, pemadatan, peratusan kehabluran dan kekuatan mampatan sampel kaca tersinter yang ditentukan melalui ujian Archimedes. Peningkatan kandungan fosfat didapati meningkatkan ketumpatan pukal dan peratusan pemadatan sampel kaca tersinter disebabkan berlaku pengurangan dalam peratusan keliangan ketara. Ini dibuktikan dengan analisis morfologi pada perbincangan seterusnya (Rajah 1 dan 2). Peratusan pemadatan yang diperoleh agak tinggi namun masih tidak mencapai $90 \%$. Ini disebabkan ciri tipikal komponen silika gel yang mempunyai luas permukaan spesifik dan isipadu keliangan yang tinggi berbanding kaca perolehan leburan sekaligus menyukarkan pemadatan partikel kaca tersinter (Chou \& Lee 1992). Peningkatan kandungan fosfat sehingga $15 \%$ mol meningkatkan peratus penghabluran kaca namun penghabluran yang berlaku didapati berkurangan dengan peningkatan fosfat sehingga $20 \%$ mol (Jadual 2). Ini disebabkan berlaku pembentukan fasa kekaca pada permukaan kaca tersinter SiCa4P4 seperti dibincangkan pada analisis morfologi (Rajah 1 dan 2). Ini menunjukkan bahawa dengan peningkatan kandungan fosfat, proses pemadatan partikel adalah lebih dominan berbanding penghabluran semasa disinter pada suhu $1200^{\circ} \mathrm{C}$. Ciri sinteran bahan kaca seperti ini adalah agak baik bagi tujuan penghasilan bahan implan perancah dengan penghabluran penuh berpotensi merencatkan sifat kebioaktifan kaca. Kesemua komposisi sampel kaca tersinter didapati mengalami penghabluran sekitar $70 \%$ yang menunjukkan kebolehupayaan sinteran kaca ini yang rendah. Peratus penghabluran yang diperoleh menunjukkan sebahagian besar fasa kaca telah menghablur namun bukan merupakan penghabluran penuh. Kajian sebelum ini melaporkan bahawa kebolehupayaan sinteran kaca sol-gel adalah agak rendah dan sekaligus membawa kepada kesukaran untuk membentuk penghabluran penuh (Touri et al. 2013).

Secara umumnya, ketiga-tiga sampel kaca tersinter membentuk dua morfologi permukaan berbeza iaitu mikrostruktur beramorfus dan berhablur seperti ditunjukkan pada Rajah 1 dan 2. Sinteran kaca membentuk penghabluran separa yang menghasilkan pecahan fasa hablur dan amorfus dalam matriks seramik kaca seperti dilaporkan dalam kajian sebelum ini (Peitl et al. 2012). Rajah 1(a)-1(c) menunjukkan morfologi beramorfus yang terhasil pada permukaan ketiga-tiga kaca tersinter dan tiada pembentukan sempadan butiran berhablur yang terhasil. Morfologi beramorfus SiCa4P menunjukkan kehadiran keliangan yang jelas terbentuk di antara butiran partikel kaca tersinter (Rajah 1(a)). Keliangan yang tinggi dalam kaca sol-gel disebabkan oleh pembentukan produk sampingan gas dan pemeluwapan sisa kimia semasa proses pemanasan gel kaca (Mukundan et al. 2013; Thomas \& Bera 2016). Peningkatan kandungan fosfat membentuk mikrostruktur beramorfus yang lebih padat dengan keliangan yang lebih rendah seperti ditunjukkan oleh kaca tersinter SiCa4P3 dan SiCa4P4 (Rajah 1(b) dan 1(c)). Mikrostruktur beramorfus SiCa4P4 juga menunjukkan peningkatan sifat kekaca justeru meningkatkan peratusan pemadatan dengan ketara disebabkan ketiadaan butiran partikel dan keliangan yang jelas terbentuk pada morfologi permukaannya (Rajah 1(c)).

Manakala morfologi berhablur yang terhasil pada permukaan ketiga-tiga kaca tersinter ditunjukkan pada Rajah 2(a)-2(c). Peningkatan kandungan fosfat didapati membentuk mikrostruktur berhablur yang lebih padat dengan keliangan lebih rendah seperti ditunjukkan oleh kaca tersinter SiCa4P3 dan SiCa4P4 (Rajah 2(b) dan 2(c)). Pembentukan butiran dan sempadan butiran berhablur yang terhasil dengan ketara menunjukkan penghabluran berlaku di dalam matriks kaca tersinter. Morfologi berhablur SiCa4P (Rajah 2(a)) didapati membentuk keliangan terutamanya pada bahagian sempadan butiran 
yang disebabkan oleh kesan pengasaran. Kesan pengasaran menyebabkan peningkatan dalam saiz liang dan butiran berhablur disebabkan pertumbuhan butiran dan keliangan yang berlaku serentak semasa disinter pada suhu tinggi (Thomas \& Bera 2016). Maka, keliangan yang terhasil pada kedua-dua morfologi berhablur dan beramorfus SiCa4P menjelaskan peratusan pemadatan jasad yang lebih rendah berbanding SiCa4P3 dan SiCa4P4 (Jadual 2). Morfologi berhablur bagi SiCa4P3 (Rajah 2(b)) membentuk butiran dan sempadan butiran berhablur yang lebih besar tanpa keliangan yang ketara berbanding SiCa4P. Ini menjelaskan sedikit peningkatan berlaku dalam peratus pemadatan dan penghabluran bagi sampel SiCa4P3 berbanding SiCa4P. Disebabkan ciri morfologi yang hampir serupa, sampel SiCa4P dan SiCa4P3 menunjukkan kekuatan mampatan maksimum sekitar $36 \mathrm{MPa}$ (Jadual 2). Oleh itu, kekuatan mampatan bagi SiCa4P dan SiCa4P3 selepas disinter didapati hanya mencapai kekuatan bagi tulang berongga ( 2 ke $45 \mathrm{MPa}$ ) dan bukannya bagi tulang kortikal manusia (90 ke $230 \mathrm{MPa}$ ) (Hannink \& Arts 2011).

Manakala butiran dan sempadan butiran berhablur serta keliangan pada morfologi berhablur SiCa4P4 (Rajah 2(c)), tidak kelihatan jelas disebabkan berlaku kesan vitrifikasi pada permukaan. Kehadiran oksida pembentuk rangkaian kaca seperti silika dan fosfat dalam jumlah tertentu membolehkan fasa leburan terhasil semasa dipanaskan dan membentuk fasa kaca apabila disejukkan (Bernardo et al. 2012). Kandungan fosfat merupakan komponen mudah meruap dalam komposisi kaca (Juhasz \& Best 2012). Selain itu, kaca yang berasaskan fosfat (> $40 \%$ mol $\mathrm{P}_{2} \mathrm{O}_{5}$ ) dileburkan pada suhu $1100^{\circ} \mathrm{C}$ (Rajendran et al. 2007; Thonglem et al. 2010) berbanding kaca berasaskan silikat yang perlu dileburkan dalam julat suhu 1350- $1550^{\circ} \mathrm{C}$ (Araújo et al. 2016; Brovarone et al. 2008; Lin et al. 2012). Ini menunjukkan fosfat mempunyai takat lebur yang relatifnya lebih rendah (sekitar $1200^{\circ} \mathrm{C}$ ) berbanding komponen lain (seperti silika) dalam kaca tersinter menyebabkannya terlebur semasa disinter dan seterusnya membentuk fasa berkaca pada permukaan. Maka, peningkatan kandungan fosfat sehingga $20 \%$ mol dipercayai menyebabkan kesan vitrifikasi pada permukaan apabila disinter pada suhu $1200^{\circ} \mathrm{C}$ dan meningkatkan kekuatan mampatan kaca tersinter SiCa4P4 kepada 113.50 MPa (Jadual 2) yang dilihat mencapai julat kekuatan bagi tulang kortikal semula jadi. Ini menunjukkan peratusan ketumpatan dan pemadatan kaca tersinter memberi kesan lebih besar terhadap peningkatan kekuatan mampatan berbanding peratusan penghabluran. Berbeza dengan laporan kajian sebelum ini yang menunjukkan peningkatan kekuatan lenturan kaca tersinter dengan peningkatan peratusan penghabluran kaca (Peitl et al. 2012). Kesan vitrifikasi permukaan ini turut menyebabkan penurunan peratusan kehabluran SiCa4P4 (Jadual 2). Ini dibuktikan dengan peningkatan ikatan kimia Si-O-Si amorfus, sekitar $470 \mathrm{~cm}^{-1}$, pada spektrum FTIR (Rajah 3) bagi kaca tersinter SiCa4P4.

Peratusan kandungan unsur pada morfologi beramorfus bagi ketiga-tiga kaca tersinter ditunjukkan pada Jadual 3 hingga 5. Didapati bahawa ketiga-tiga morfologi beramorfus mengandungi unsur tertinggi iaitu $\mathrm{Si}$ dan $\mathrm{O}$ dengan turutan peratusan unsur iaitu $\mathrm{O}>\mathrm{Si}>\mathrm{Ca}>\mathrm{P}$. Oleh itu, komponen unsur Si-O berperanan penting dalam membentuk fasa beramorfus (fasa kaca) dalam matriks kaca tersinter. Ini selari dengan peranan silika $\left(\mathrm{SiO}_{2}\right)$ sebagai pembentuk rangkaian utama kaca silikat dengan membentuk rangkaian 3D tetrahedra Si-O-Si. Kandungan silika lebih tinggi dalam komposisi kaca sol-gel diketahui meningkatkan struktur beramorfus kaca (Bernardo et al. 2012; Juhasz \& Best 2012). Peningkatan kandungan fosfat didapati meningkatkan peratusan unsur Si pada morfologi beramorfus terutamanya bagi kaca tersinter SiCa4P4 (Jadual 5). Peningkatan peratusan Si pada morfologi beramorfus dengan peningkatan kandungan fosfat ini boleh dikaitkan dengan pemisahan fasa yang berlaku dalam matriks kaca seperti yang dibincangkan dalam analisis FTIR (topik 2.0). Maka, peningkatan peratusan Si ini dipercayai menyebabkan berlakunya peningkatan ciri kekaca pada morfologi beramorfus seperti yang telah dinyatakan pada analisis morfologi sebelum ini (Rajah 1(c)).

Manakala peratusan kandungan unsur pada morfologi berhablur ketiga-tiga kaca tersinter ditunjukkan pada Jadual 6 hingga 8. Komponen $\mathrm{Ca}$ dan $\mathrm{O}$ merupakan peratusan unsur yang tertinggi pada ketiga-tiga morfologi fasa berhablur. Ini menunjukkan bahawa, selain bertindak sebagai pengubahsuai rangkaian kaca, komponen $\mathrm{Ca}-\mathrm{O}$ berperanan sebagai pembentuk fasa berhablur dalam matriks kaca tersinter. Ini memberikan indikasi bahawa fasa berhablur berasaskan Ca terbentuk pada ketiga-tiga matriks kaca tersinter. Kajian sebelum ini menunjukkan bahawa kawalan terhadap komposisi fasa berhablur dalam matriks kaca tersinter dapat dilakukan dengan mengubah kandungan kalsium oksida kaca (Araújo et al. 2016). Kaca

JADUAL 2. Nilai ketumpatan, keliangan, pemadatan, penghabluran dan kekuatan mampatan sampel kaca dengan komposisi fosfat berbeza selepas disinter pada suhu $1200^{\circ} \mathrm{C}$

\begin{tabular}{lccc}
\hline \multicolumn{1}{c}{ Sifat } & SiCa4P & SiCa4P3 & SiCa4P4 \\
\hline Ketumpatan pukal & $1.49 \mathrm{gm} / \mathrm{cm}^{3}$ & $1.80 \mathrm{gm} / \mathrm{cm}^{3}$ & $2.10 \mathrm{gm} / \mathrm{cm}^{3}$ \\
Keliangan ketara & $39.56 \%$ & $29.52 \%$ & $16.44 \%$ \\
Pemadatan & $60.44 \%$ & $70.48 \%$ & $83.56 \%$ \\
Penghabluran & $75.8 \%$ & $76.4 \%$ & $66.1 \%$ \\
Kekuatan mampatan & $36.05 \mathrm{MPa}$ & $35.06 \mathrm{MPa}$ & $113.50 \mathrm{MPa}$ \\
\hline
\end{tabular}




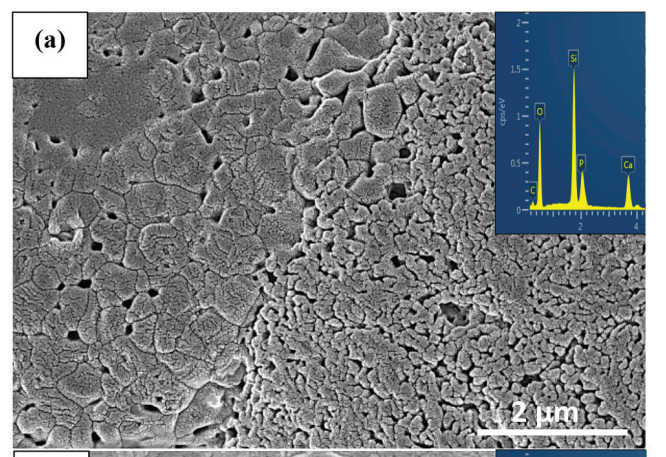

\begin{tabular}{cc}
\multicolumn{2}{c}{ JADUAL 3 } \\
\hline Unsur & (\% berat) \\
\hline $\mathrm{O}$ & 36.28 \\
$\mathrm{Si}$ & 30.06 \\
$\mathrm{Ca}$ & 26.83 \\
$\mathrm{P}$ & 6.83 \\
\hline
\end{tabular}

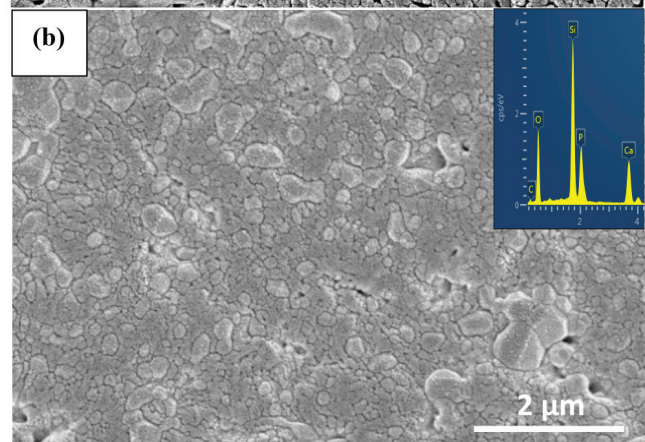

JADUAL 4

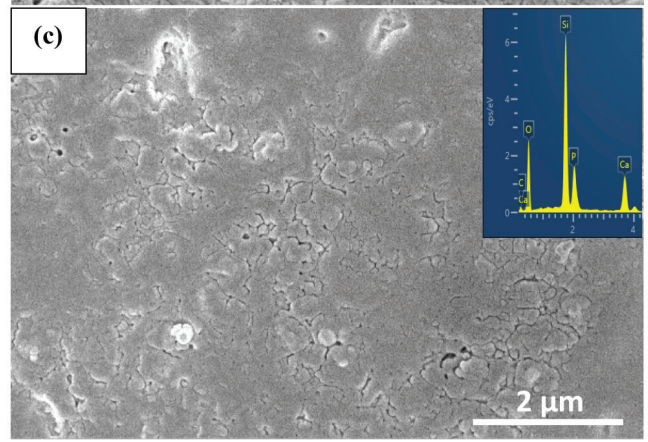

JADUAL 5

\begin{tabular}{cc}
\hline Unsur & (\% berat) \\
\hline $\mathrm{O}$ & 39.84 \\
$\mathrm{Si}$ & 30.34 \\
$\mathrm{Ca}$ & 18.78 \\
$\mathrm{P}$ & 11.04 \\
\hline
\end{tabular}

\begin{tabular}{cc}
\multicolumn{2}{c}{ JADUAL 5 } \\
\hline Unsur & $(\%$ berat $)$ \\
\hline $\mathrm{O}$ & 38.34 \\
$\mathrm{Si}$ & 37.44 \\
$\mathrm{Ca}$ & 15.85 \\
$\mathrm{P}$ & 8.37 \\
\hline
\end{tabular}

RAJAH 1. Morfologi beramorfus bagi sampel (a) SiCa4P (b) SiCa4P3 (c) SiCa4P4 beserta kandungan unsur (Jadual 3, 4 dan 5) selepas disinter pada suhu $1200^{\circ} \mathrm{C}$

tersinter $\mathrm{SiCa} 4 \mathrm{P}$ dan $\mathrm{SiCa} 4 \mathrm{P} 3$ mengandungi peratusan unsur dengan turutan ketinggian $\mathrm{Ca}>\mathrm{O}>\mathrm{Si}>\mathrm{P}$ pada mikrostruktur berhablur (Jadual 6 \& 7). Sebaliknya, $\mathrm{SiCa} 4 \mathrm{P} 4$ mengandungi peratusan unsur dengan turutan ketinggian iaitu $\mathrm{Ca}>\mathrm{O}>\mathrm{P}>$ Si pada morfologi berhablur yang mana unsur $\mathrm{P}$ meningkat melebihi peratusan unsur $\mathrm{Si}$ (Jadual 8). Ini menunjukkan peningkatan kandungan fosfat sehingga $20 \%$ mol meningkatkan peratusan unsur $\mathrm{P}$ pada morfologi berhablur (pada masa sama meningkatkan unsur Si pada morfologi beramorfus). Ini boleh dikaitkan dengan pemisahan fasa kaya fosfat dan silikat yang berlaku dengan peningkatan kandungan fosfat yang dibincangkan dalam analisis FTIR. Selain itu, peningkatan unsur P pada morfologi berhablur ini boleh dikaitkan dengan kesan vitrifikasi yang berlaku pada morfologi permukaan kaca tersinter. Kehadiran komponen oksida pembentuk kaca seperti fosfat $\left(\mathrm{P}_{2} \mathrm{O}_{5}\right)$ dalam jumlah mencukupi membolehkan pembentukan fasa berkaca (kesan vitrifikasi) apabila dipanaskan pada takat leburan (Bernardo et al. 2012). Ini menunjukkan kesan vitrifikasi yang berlaku pada morfologi berhablur adalah serentak dengan peningkatan unsur P pada morfologi berhablur kaca tersinter. Maka ini membuktikan bahawa peningkatan kandungan fosfat sehingga $20 \%$ mol yang disinter pada suhu $1200^{\circ} \mathrm{C}$ meningkatkan kandungan unsur $\mathrm{P}$ pada morfologi berhablur lantas membolehkan fasa berkaca terbentuk pada morfologi permukaan kaca tersinter SiCa4P4.

\section{ANALISIS KUMPULAN BERFUNGSI}

Spektrum FTIR bagi ketiga-tiga sampel kaca tersinter ditunjukkan pada Rajah 3. Kaca tersinter SiCa4P didapati membentuk kumpulan berfungsi berkaitan silikat seperti ditunjukkan pada Rajah 3(a). Ini merujuk kepada kehadiran puncak spektrum iaitu $1090 \mathrm{~cm}^{-1}$ (regangan $\mathrm{Si}-\mathrm{O}-\mathrm{Si}$ ) (Ma et al. 2010), 1060-1080 $\mathrm{cm}^{-1}$ (lenturan asimetri SiO-Si) (Catauro et al. 2015), $990 \mathrm{~cm}^{-1}$ (lenturan asimetri $\mathrm{Si}-\mathrm{O}-\mathrm{Si}$ ), $940 \mathrm{~cm}^{-1}$ (regangan simetri Si-O) (Radev et al. 2010), $800-810 \mathrm{~cm}^{-1}$ (lenturan asimetri $\mathrm{Si}-\mathrm{O}-\mathrm{Si}$ ) (Catauro et al. 2015), $717 \mathrm{~cm}^{-1}$ (lenturan Si-O) (Radev et al. 2010) dan $470 \mathrm{~cm}^{-1}$ (goyangan Si-O-Si) (Ma et al. 2010). Peningkatan kandungan fosfat didapati meningkatkan 


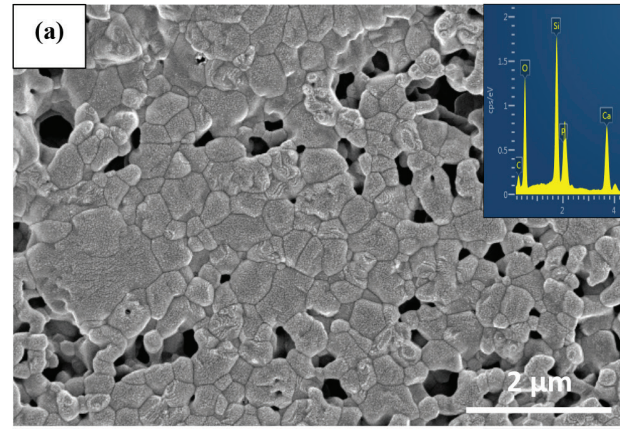

\begin{tabular}{cc}
\multicolumn{2}{c}{ JADUAL 6 } \\
\hline Unsur & (\% berat $)$ \\
\hline $\mathrm{O}$ & 36.19 \\
$\mathrm{Si}$ & 23.41 \\
$\mathrm{Ca}$ & 36.90 \\
$\mathrm{P}$ & 3.51 \\
\hline
\end{tabular}

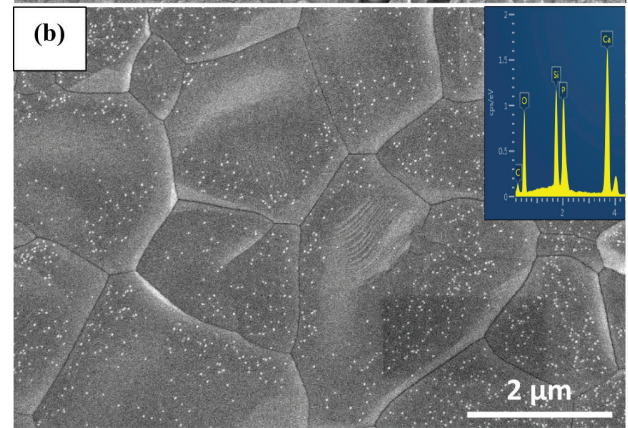

JADUAL 7

\begin{tabular}{cc}
\hline Unsur & (\% berat $)$ \\
\hline $\mathrm{O}$ & 37.09 \\
$\mathrm{Si}$ & 10.62 \\
$\mathrm{Ca}$ & 37.49 \\
$\mathrm{P}$ & 9.96 \\
\hline
\end{tabular}

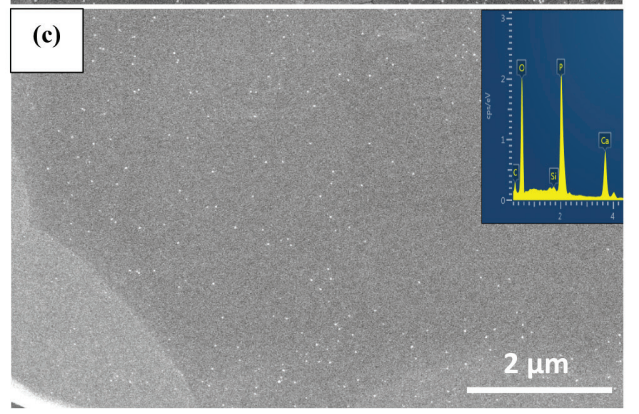

JADUAL 8

\begin{tabular}{cc}
\hline Unsur & $(\%$ berat $)$ \\
\hline $\mathrm{O}$ & 37.64 \\
$\mathrm{Si}$ & 0.73 \\
$\mathrm{Ca}$ & 39.14 \\
$\mathrm{P}$ & 22.48 \\
\hline
\end{tabular}

RAJAH 2. Morfologi berhablur bagi sampel (a) SiCa4P (b) SiCa4P3 (c) SiCa4P4 beserta kandungan unsur (Jadual 6,7 dan 8) selepas disinter pada suhu $1200^{\circ} \mathrm{C}$

pembentukan kumpulan berfungsi berkaitan fosfat ( $\mathrm{P}$ O) seperti ditunjukkan pada spektrum FTIR bagi kaca tersinter SiCa4P3 dan SiCa4P4 (Rajah 3(b) dan 3(c)). Ini merujuk kepada kehadiran puncak spektrum sekitar $1210 \mathrm{~cm}^{-1}$ (regangan asimetri kumpulan P-O dalam unit struktur $\mathrm{Q}^{1}$ ) (Catauro et al. 2015), $1140 \mathrm{~cm}^{-1}$ (lenturan Si-O-P) (Zhao et al. 2010), $1030 \mathrm{~cm}^{-1}$ (regangan P-O) dan $1000 \mathrm{~cm}^{-1}$ (lenturan P-O-P didalam $\mathrm{P}_{2} \mathrm{O}_{5}$ ) (Mozafari et al. 2010). Kehadiran kumpulan berfungsi Si-O-P dan P-O-P menunjukkan berlaku pembentukan rangkaian 3D tetrahedra silikat-fosfat kaca yang lebih stabil dengan peningkatan kandungan fosfat (Araújo et al. 2016). Kehadiran puncak spektrum berkembar pada 609 dan 565 $\mathrm{cm}^{-1}$ (P-O hablur) menunjukkan kehadiran fasa berhablur fosfat dalam matriks kaca tersinter (Bizari et al. 2013).

Dengan peningkatan kandungan fosfat (Rajah 3(a), 3(b) dan 3(c)), didapati berlaku anjakan dan perubahan keamatan puncak spektrum berkembar pada 609 dan $565 \mathrm{~cm}^{-1}$ (P-O hablur) kepada puncak lebih lebar pada julat $570-610 \mathrm{~cm}^{-1}$. Puncak yang terhasil pada julat ini merujuk kepada mod getaran P-O yang sering dikaitkan dengan kumpulan P-O dalam kalsium fosfat amorfus (Kim et al. 1992; Saboori et al. 2009). Ini memberi indikasi bahawa terdapat pembentukan ikatan kimia $\mathrm{P}-\mathrm{O}$ amorfus di dalam matriks kaca tersinter SiCa4P4 (Rajah 3(c)). Maka, kehadiran fosfat amorfus ini boleh dikaitkan dengan analisis morfologi sebelum ini yang menunjukkan pembentukan fasa berkaca pada morfologi berhablur kaca tersinter SiCa4P4 (Rajah 2(c)). Ini turut menyokong perbincangan sebelum ini bahawa peningkatan fosfat sehingga $20 \%$ mol membentuk fasa fosfat berkaca pada morfologi kaca tersinter SiCa4P4 disebabkan kesan vitrifikasi semasa sinteran pada suhu $1200^{\circ} \mathrm{C}$.

Peningkatan kandungan fosfat didapati meningkatkan puncak spektrum sekitar $800 \mathrm{~cm}^{-1}$ yang merujuk kepada oksigen penghubung (BO) antara tetrahedra Si-O-Si (Rajah 3(a), 3(b) dan 3(c)). Ini menunjukkan pempolimeran rangkaian tetrahedra silikat $(\mathrm{Si}-\mathrm{O}-\mathrm{Si})$ dan fosfat (P-O-P) kaca meningkat dengan peningkatan kandungan fosfat. Selain itu, peningkatan pempolimeran rangkaian tetrahedra ini menyebabkan struktur amorfus kaca tersinter meningkat seperti yang ditunjukkan dengan peningkatan puncak spektrum sekitar $470 \mathrm{~cm}^{-1}$ (Si-O-Si amorfus) (Rajah 3(a), 3(b) dan 3(c)). Ini turut membuktikan peningkatan peratusan unsur Si pada morfologi beramorfus SiCa4P4 (akibat peningkatan kandungan fosfat sehingga 20\% mol) 
menyebabkan berlakunya peningkatan ciri berkaca pada morfologi tersebut (rujuk analisis morfologi dan unsur permukaan sebelum ini (Rajah 1(c)).

Peningkatan kandungan fosfat sehingga $20 \%$ mol (sampel SiCa4P4) membentuk puncak spektrum dengan keamatan lebih tinggi dan lebar terutamanya pada julat 900-1200 $\mathrm{cm}^{-1}$ (Rajah 3(c)). Ini menunjukkan terdapat pertindihan spektrum bagi rangkaian tetrahedra silikat dan fosfat kaca yang menyebabkan keamatan puncak spektrum meningkat (Bellucci et al. 2010; Lefebvre et al. 2008). Menurut kajian sebelum ini, pertindihan kedua-dua spektrum tetrahedra ini menunjukkan berlaku pembentukan dan pemisahan fasa kaya silikat dan fasa kaya fosfat dalam matriks kaca tersinter. Fenomena ini dijangkakan apabila dua ion valensi tinggi seperti $\mathrm{Si}^{4+}$ dan $\mathrm{P}^{5+}$ hadir bersama-sama dalam komposisi kaca (Araújo et al. 2016; Bellucci et al. 2010; Lefebvre et al. 2008). Seperti yang telah dibincangkan dalam analisis morfologi dan unsur permukaan, peningkatan kandungan fosfat sehingga $20 \%$ mol meningkatkan peratusan unsur P pada morfologi berhablur dan pada masa sama meningkatkan peratusan unsur Si pada morfologi beramorfus kaca tersinter (Jadual 5 dan 8). Keputusan tersebut boleh dikaitkan dengan peningkatan pempolimeran rangkaian tetrahedra silikat dan fosfat kaca tersinter serta pemisahan fasa kaya silikat dan fasa kaya fosfat yang berlaku di dalam matriks kaca tersinter seperti yang ditunjukkan dalam analisis FTIR ini.

\section{ANALISIS FASA DAN PENGHABLURAN}

Corak penyerakan sinar-X (XRD) bagi sampel kaca tersinter dengan komposisi fosfat berbeza ditunjukkan pada Rajah 4. Senarai fasa yang hadir dan peratus penghabluran yang terhasil bagi ketiga-tiga sampel kaca tersinter ditunjukkan dalam Jadual 9. Kesemua sampel menunjukkan kehadiran fasa amorfus dan fasa berhablur dalam matriks kaca tersinter. Peningkatan kandungan fosfat mengurangkan peratus penghabluran kaca tersinter daripada $75 \%$ ke $66 \%$ (Jadual 9). Telah dibincangkan sebelum ini bahawa peningkatan kandungan fosfat meningkatkan rangkaian tetrahedra silikat dan menghasilkan kesan vitrifikasi pada permukaan. Ini menyebabkan berlaku peningkatan ikatan Si-O-Si amorfus dan pembentukan fasa kekaca pada permukaan sekaligus menurunkan peratusan kehabluran kaca. Didapati bahawa, ketiga-tiga sampel membentuk fasa hablur silikokarnotit, $\mathrm{Ca}_{5}\left(\mathrm{PO}_{4}\right)_{2}\left(\mathrm{SiO}_{4}\right)$ (ICSD 98-001-2259) dan fasa hablur kalsium fosfat silikat, $\mathrm{Ca}_{14.92}\left(\mathrm{PO}_{4}\right)_{2.35}\left(\mathrm{SiO}_{4}\right)_{5.65}$ (ICSD 98-0046851) dalam matrik kaca tersinter. Pembentukan keduadua fasa berhablur ini berasaskan kepada komposisi kaca sol-gel yang dihasilkan iaitu $\mathrm{SiO}_{2}-\mathrm{CaO}-\mathrm{P}_{2} \mathrm{O}_{5}$. Peningkatan kandungan fosfat didapati meningkatkan pembentukan fasa silikokarnotit dan pada masa sama mengurangkan pembentukan fasa kalsium fosfat (V) silikat (Jadual 9).

Analisis spektrum FTIR sebelum ini (Rajah 3) menunjukkan berlaku peningkatan terhadap fasa kaya fosfat dan pengurangan terhadap fasa kaya silikat pada sampel kaca tersinter dengan peningkatan kandungan fosfat. Fasa silikokarnotit $\mathrm{Ca}_{5}\left(\mathrm{PO}_{4}\right)_{2}\left(\mathrm{SiO}_{4}\right)$ dilihat mempunyai kandungan struktur fosfat $\left(\mathrm{PO}_{4}\right)$ yang lebih tinggi berbanding kandungan silikat $\left(\mathrm{SiO}_{4}\right)$. Manakala fasa kalsium fosfat (v) silikat $\mathrm{Ca}_{14.92}\left(\mathrm{PO}_{4}\right)_{2.35}\left(\mathrm{SiO}_{4}\right)_{5.65}$ dilihat mempunyai kandungan silikat $\left(\mathrm{SiO}_{4}\right)$ yang lebih tinggi berbanding kandungan fosfat $\left(\mathrm{PO}_{4}\right)$. Disebabkan itu, peningkatan kandungan fosfat membawa kepada peningkatan pembentukan fasa silikokarnotit dan pengurangan terhadap pembentukan fasa kalsium fosfat (v) silikat.

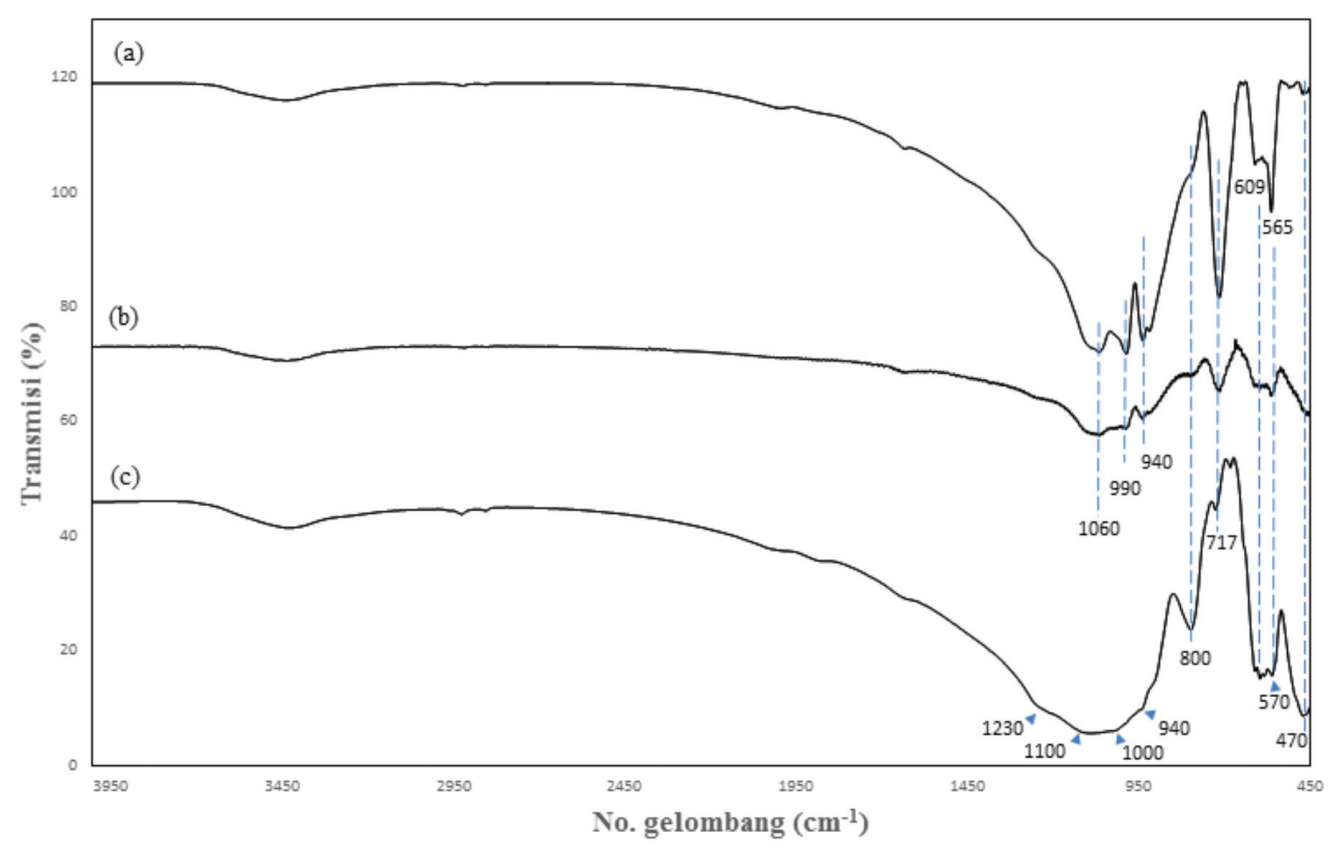

RAJAH 3. Spektrum FTIR bagi sampel (a) SiCa4P, (b) SiCa4P3 dan (c) SiCa4P4 dengan komposisi fosfat berbeza selepas disinter pada suhu $1200^{\circ} \mathrm{C}$ 


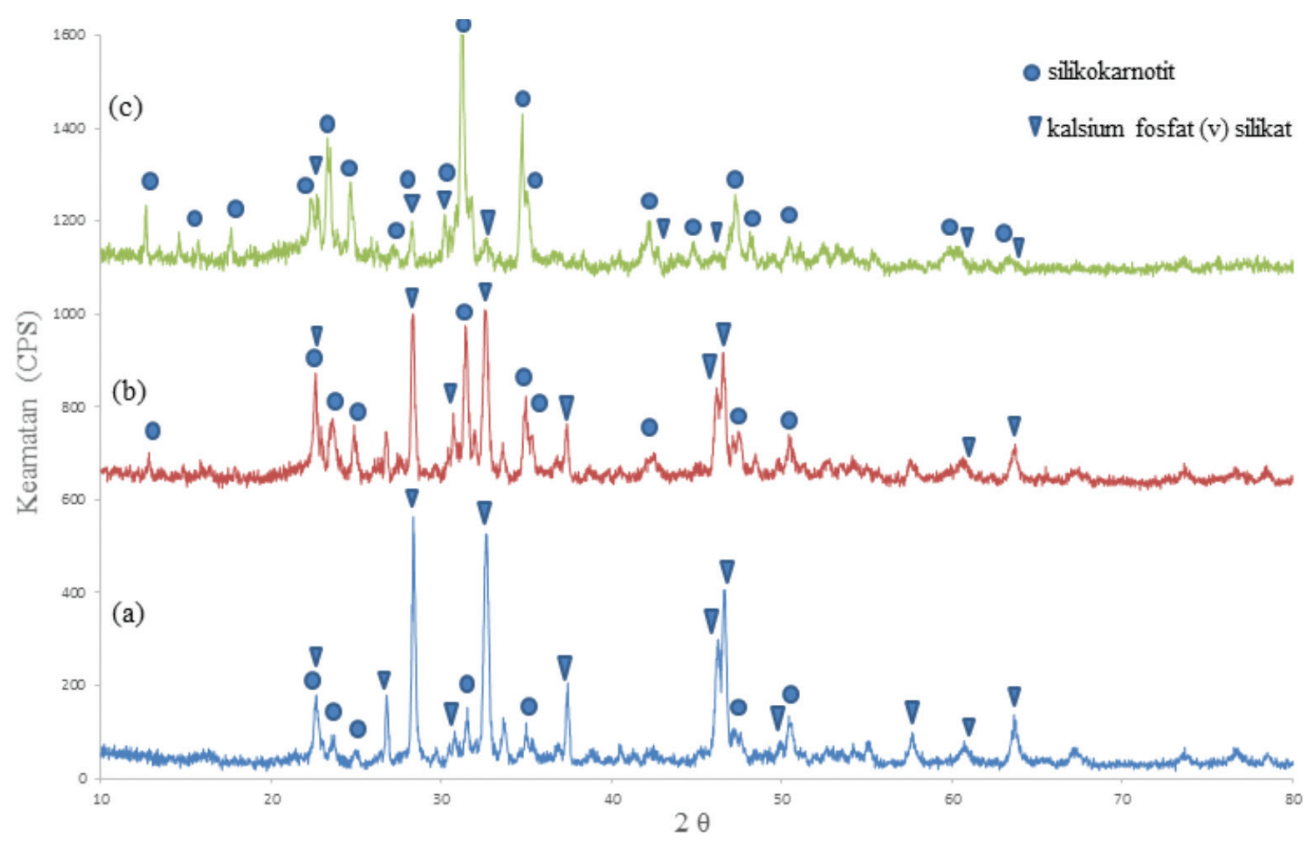

RAJAH 4. Diffraktogram XRD bagi sampel (a) SiCa4P, (b) SiCa4P3 dan (c) SiCa4P4 dengan komposisi fosfat berbeza selepas disinter pada suhu $1200^{\circ} \mathrm{C}$

JADUAL 9. Peratusan penghabluran dan komposisi fasa hablur yang terhasil bagi setiap sampel kaca dengan komposisi fosfat berbeza selepas disinter pada suhu $1200^{\circ} \mathrm{C}$

\begin{tabular}{cccc}
\hline Kaca tersinter & Penghabluran $(\%)$ & & Fasa yang hadir (\%) \\
\hline SiCa4P & 75.80 & Silikokarnotit (22.8) & Kalsium Fosfat (V) Silikat (77.2) \\
SiCa4P3 & 76.40 & Silikokarnotit (58.7) & Kalsium Fosfat (V) Silikat (41.3) \\
SiCa4P4 & 66.10 & Silikokarnotit (94.8) & Kalsium Fosfat (V) Silikat (5.2) \\
\hline
\end{tabular}

\section{KESIMPULAN}

Penyediaan dan pencirian kaca sol-gel berasaskan komposisi pertigaan $\mathrm{SiO}_{2} \cdot \mathrm{CaO} \cdot \mathrm{P}_{2} \mathrm{O}_{5}$ dengan komposisi fosfat berbeza yang disinter pada suhu $1200^{\circ} \mathrm{C}$ telah berjaya dijalankan. Kandungan fosfat berbeza dalam komposisi kaca sol-gel menghasilkan morfologi permukaan, keliangan, pemadatan, kumpulan berfungsi, fasa dan penghabluran yang berbeza setelah disinter. Ini memberikan kesan langsung terhadap kekuatan mampatan maksimum kaca tersinter. Peningkatan sehingga $20 \%$ mol kandungan fosfat didapati berjaya meningkatkan kekuatan mampatan kaca tersinter sehingga 113 MPa yang berada dalam julat kekuatan mampatan bagi tulang kortikal semula jadi. Walau bagaimanapun, ujian kebioaktifan in vitro bagi sampel kaca tersinter ini perlu dilakukan bagi mengenal pasti kesan terhadap sifat kebioaktifan bahan akibat peningkatan sifat mekanikal yang terhasil.

\section{PENGHARGAAN}

Kami ingin merakamkan setinggi-tinggi perhargaan kepada Universiti Kebangsaan Malaysia dan Kementerian Pengajian Tinggi, Malaysia atas bantuan kewangan melalui geran universiti (2012-077) dan Skim Geran Penyelidikan
Asas (9003-00483) serta Universiti Malaysia Perlis atas bantuan teknikal dan peralatan pengujian sampel.

\section{RUJUKAN}

Adams, L.A., Essien, E.R., Shaibu, R.O. \& Oki, A. 2013. Solgel synthesis of $\mathrm{SiO} 2-\mathrm{CaO}-\mathrm{Na} 2 \mathrm{O}-\mathrm{P} 2 \mathrm{O} 5$ bioactive glass ceramic from sodium metasilicate. New Journal of Glass and Ceramics 3(1): 11-15.

Araújo, M., Miola, M., Baldi, G., Perez, J. \& Verné, E. 2016. Bioactive glasses with low $\mathrm{Ca} / \mathrm{P}$ ratio and enhanced bioactivity. Materials 226(9): 1-15.

Arcos, D. \& Vallet-regí, M. 2010. Sol-gel silica based biomaterials and bone tissue regeneration. Acta Biomaterialia 6(8): 2874-2888.

Bizari, D., Rabiee, M., Moztarzadeh,F., Tahriri, M.,Alavi, S.H. \& Masaeli, R. 2013. Synthesis, characterization and biological evaluation of sol-gel derived nanomaterial in the ternary syntem $64 \% \mathrm{SiO} 2-31 \% \mathrm{CaO}-5 \% \mathrm{P} 2 \mathrm{O} 5$ as a bioactive glass: in vitro study. Ceramics - Silikaty 57(3): 201-209.

Bellucci, D., Cannillo, V. \& Sola, A. 2010. An overview of the effects of thermal processing on bioactive glasses. Science of Sintering 42(3): 307-320.

Bernardo, E., Scarinci G. \& Colombo P. 2012. Vitrification of waste and reuse of waste-derived glass. In Encyclopedia of Sustainability Science and Technology, edited by Meyers, R.A. New York: Springer. 
Brovarone, C.V., Miola, M., Balagna, C. \& Verne, E. 2008. 3D-glass-ceramic scaffolds with antibacterial properties for bone grafting. Chemical Engineering Journal 137(1): 129-136.

Catauro, M., Bollino, F., Renella, R.A.\& Papale, F. 2015. Sol-gel synthesis of $\mathrm{SiO} 2-\mathrm{CaO}-\mathrm{P} 2 \mathrm{O} 5$ glasses: Influence of the heat treatment on their bioactivity and biocompatibility. Ceramics International 41(10): 12578-12588.

Chou, K.T. \& Lee, B.I. 1992. Properties of silica gels prepared from high-acid hydrolysis of tetraethoxysilane. Ceramics International 19(5): 315-325.

Esfehani, F., Baghshaei, S., Asghar, A. \& Ghader, B. 2013. The effects of $\mathrm{CaO} / \mathrm{P} 2 \mathrm{O} 5$ molar ratio changes on in vitro bioactivity of nanopowder glass via sol-gel in $\mathrm{SiO}_{2}-\mathrm{CaO}-\mathrm{P}_{2} \mathrm{O}_{5}$ system. Basic and Applied Scientific Research 3(1s): 375-382.

Hannink, G. \& Arts, J.J.C. 2011. Bioresorbability, porosity and mechanical strength of bone substitutes: What is optimal for bone regeneration? Injury 42: S22-S25.

Jones, J.R. 2013. Acta biomaterialia review of bioactive glass: From Hench to hybrids. Acta Biomaterialia 9(1): 4457-4486.

Juhasz, J.A. \& Best, S.M. 2012. Bioactive ceramics: Processing, structures and properties. Journal of Material Science 47(2): 610-624.

Kim, C.Y., Clark, A.E. \& Hench, L.L. 1992. Compositional dependence of calcium phosphate layer formation in fluoride Bioglasses. Journal of Biomedical Materials Research 26(9): 1147-1161.

Lefebvre, L., Gremillard, L., Chevalier, J.,Zenati, R. \& BernacheAssolant, D. 2008. Sintering behaviour of 45S5 bioactive glass. Acta Biomaterialia 4(6): 1894-1903.

Lin, C.C., Chen, S.F., Leung, K.S. \& Shen, P. 2012. Effects of $\mathrm{CaO} / \mathrm{P} 2 \mathrm{O} 5$ ratio on the structure and elastic properties of $\mathrm{SiO} 2-\mathrm{CaO}-\mathrm{Na} 2 \mathrm{O}-\mathrm{P} 2 \mathrm{O} 5$ bioglasses. Journal of Materials Science: Materials in Medicine 23(2): 245-258.

Lombardi, M., Gremillard, L., Chevalier, J., Lefebvre, L., Cacciotti, I., Bianco, A. \& Montanaro, L. 2013. A comparative study between melt-derived and sol-gel synthesized 45S5 bioactive glasses. Key Engineering Materials 541: 15-30.

Ma, J., Chen, C.Z., Wang, D.G., Meng, X.G. \& Shi, J.Z. 2010. Influence of the sintering temperature on the structural feature and bioactivity of sol-gel derived $\mathrm{SiO} 2-\mathrm{CaO}-\mathrm{P} 2 \mathrm{O} 5$ bioglass . Ceramics International 36(22): 1911-1916.

Mozafari, M., Moztarzadeh, F. \& Tahriri, M. 2010. Investigation of the physico-chemical reactivity of a mesoporous bioactive $\mathrm{SiO} 2-\mathrm{CaO}-\mathrm{P} 2 \mathrm{O} 5$ glass in simulated body fluid. Journal of Non-Crystalline Solids 356(28-30): 1470-1478.

Mukundan, L.M., Vaikkath, R.N.D. \& Nair, P.D. 2013. A new synthesis route to high surface area sol gel bioactive glass through alcohol washing. Biomatter 3(2): e242881-e24288-10.

Oliveira, A.A.R., Souza, D.A., Dias, L.L.S., Carvalho, S., Sander, M.H., Magalh, D. \& Pereira, M.M. 2013. Synthesis, characterization and cytocompatibility of spherical bioactive glass nanoparticles for potential hard tissue engineering applications. Biomedical Materials 8(2): 1050-1062.

Peitl, O., Dutra, E. \& Hench, L.L. 2001. Highly bioactive P2O5. $\mathrm{Na} 2 \mathrm{O} . \mathrm{CaO} . \mathrm{SiO} 2$ glass-ceramics. Non Crystalline Solids 292(1-3): 115-126.

Peitl, O., Zanotto, E.D., Serbena, F.C. \& Hench, L.L 2012. Compositional and microstructural design of highly bioactive P2O5-Na2O-CaO-SiO2 glass-ceramics. Acta Biomaterialia 8(1): 321-332.
Rahaman, M.N., Day, D.E., Bal, B.S., Fu, Q., Jung, S.B., Bonewald, L.F. \& Tomsia, A.P. 2011. Acta biomaterialia bioactive glass in tissue engineering. Acta Biomaterialia 7(6): 2355-2373.

Radev, L., Hristov, V., Michailova, I., Fernandes, M.H.V. \& Salvado, I.M.M. 2010. In vitro bioactivity of biphasic calcium phosphate silicate glass ceramic in $\mathrm{CaO}-\mathrm{SiO} 2-\mathrm{P} 2 \mathrm{O} 5$ system . Processing and Application of Ceramics 4(1): 15-24.

Rajendran, V., Devi, A.V.G., Azooz, M. \& El-Batal, F.H. 2007. Physicochemical studies of phosphate based P2O5-Na2O$\mathrm{CaO}-\mathrm{TiO} 2$ glasses for biomedical applications. Journal of Non-Crystalline Solids 353(1): 77-84.

Ravarian, R., Wei, H. \& Dehghani, F. 2011. Improving the bioactivity of bioglass/(PMMA-Co-MPMA) organic/ inorganic hybrid. 33rd Annual International Conference of the IEEE EMBS: 3593-3596.

Saboori, A., Rabiee, M., Moztarzadeh, F., Sheikhi, M., Tahriri, M. \& Karimi, M. 2009. Synthesis, characterization and in vitro bioactivity of sol-gel-derived $\mathrm{SiO} 2-\mathrm{CaO}-\mathrm{P} 2 \mathrm{O} 5-\mathrm{MgO}$ bioglass. Materials Science and Engineering C 29(1): 335340 .

Salinas, A.J., Martin, A.I. \& Vallet-Regí, M. 2002. Bioactivity of three $\mathrm{CaO}-\mathrm{P} 2 \mathrm{O} 5-\mathrm{SiO} 2$ sol-gel glasses. Journal of Biomedical Materials Research 61(4): 524-532.

Thomas, A. \& Bera, J. 2016. Crystallization and sintering behavior of glass-ceramic powder synthesized by sol-gel process. Journal of The Australian Ceramic Society Volume 52(2): 87-91.

Thonglem, S., Pengpat, K., Rujijanagul, G., Eitssayeam, S., Punyanitya, S. \& Tunkasiri, T. 2010. Effects of $\mathrm{CaO}$ on properties of $\mathrm{P} 2 \mathrm{O} 5-\mathrm{CaO}-\mathrm{Na} 2 \mathrm{O}$ glasses and glass ceramics. Journal of Metals, Materials and Minerals 20(3): 173-177.

Touri, R., Moztarzadeh, F., Sadeghian, Z., Bizari, D., Tahriri, M. \& Mozafari, M. 2013. The use of carbon nanotubes to reinforce $45 \mathrm{~S} 5$ bioglass-based scaffolds for tissue engineering applications. BioMed Research International 2013: Article ID. 465086.

Yang, X., Zhang, L., Chen, X., Sun, X., Yang, G., Guo, X. \& Gou, Z. 2012. Incorporation of $\mathrm{B} 2 \mathrm{O} 3$ in $\mathrm{CaO}-\mathrm{SiO} 2-\mathrm{P} 2 \mathrm{O} 5$ bioactive glass system for improving strength of low-temperature co- $\mathrm{fi}$ red porous glass ceramics. Journal of Non-Crystalline Solids 358(9): 1171-1179.

Zhao, S., Li, Y. \& Li, D. 2010. Synthesis and in vitro bioactivity of $\mathrm{CaO}-\mathrm{SiO} 2-\mathrm{P} 2 \mathrm{O} 5$ mesoporous microspheres. Microporous and Mesoporous Materials 135(1-3): 67-73.

Syed Nuzul Fadzli Syed Adam* \& Roslinda Shamsudin

School of Applied Physics

Faculty of Science and Technology

Universiti Kebangsaan Malaysia

43600 UKM Bangi, Selangor Darul Ehsan

Malaysia

Firuz Zainuddin

School of Materials Engineering

Universiti Malaysia Perlis

02600 Arau, Perlis Indera Kayangan

Malaysia

Mohd Reusmaazran Yusof

Material Technology Group, Industrial Technology Department Malaysia Nuclear Agency 
43000 Kajang, Selangor Darul Ehsan

Malaysia

*Pengarang untuk surat-menyurat; email: syed.nuzul@unimap.
Diserahkan: 12 Oktober 2017

Diterima: 29 Januari 2018

edu.my 